\title{
The effect of PM10 on allergy symptoms in allergic rhinitis patients during spring season
}

\author{
Joo Hyun Jung \\ From 3rd WAO International Scientific Conference (WISC) 2014 \\ Rio de Janeiro, Brazil. 6-9 December 2014
}

\section{Background}

PM10 (particulate matter less than $10 \mu \mathrm{m}$ ) is known as a major air pollutant component that affects allergy symptoms. We have studied the effects of PM10 on allergy symptoms in allergic rhinitis patients during the spring season.

\section{Methods}

We have reviewed allergic symptoms score changes in 108 allergic patients and in 47 healthy controls by evaluating their 120-day symptom diariesfrom February to May 2012. At the same time, the pollen counts and PM10 concentration were also assessed by the city environmental center. We have compared the symptom scores before and 2 days after the PM10 concentration was elevated over $100 \mu \mathrm{g} / \mathrm{m}^{3}$. Additionally, we have also investigated long-term, 120-day observations.

\section{Results}

The PM10 concentration during the 120-days was less than $150 \mu \mathrm{g} / \mathrm{m}^{3}$. There were no significant correlations between the PM10 concentration change and allergic symptom scoresor drug usage. Allergic symptomswere significantly correlated, however, with pollen counts and out-door activity times $(P<0.001)$.

\section{Conclusions}

This study demonstrates that PM10 concentrations(less than $150 \mu \mathrm{g} / \mathrm{m}^{3}$ ) did not influenceallergy symptoms in allergic rhinitis patients during the ASD season in 2012 year.

Published: 8 April 2015

Gachoon University, Gil Hospital, South Korea
doi:10.1186/1939-4551-8-S1-A35

Cite this article as: Jung: The effect of PM10 on allergy symptoms in allergic rhinitis patients during spring season. World Allergy Organization Journal 2015 8(Suppl 1):A35.
Submit your next manuscript to BioMed Central and take full advantage of:

- Convenient online submission

- Thorough peer review

- No space constraints or color figure charges

- Immediate publication on acceptance

- Inclusion in PubMed, CAS, Scopus and Google Scholar

- Research which is freely available for redistribution 